\title{
XIMIЧHI CEHCOPИ
}

\section{CHEMICAL SENSORS}

PACS 73.20.DX, 85.42.+M

УДК 537.312, 535.37

\section{ГАЗОАДСОРБЦІЙНІ СЕНСОРНІ СТРУКТУРИ НА ОСНОВІ ПОРУВАТОГО КРЕМНІЮ}

\author{
Л. С. Монастирський, І. Б. Оленич, О. І. Аксіментьєва, \\ Б. С. Соколовський, М. Р. Павлик \\ Львівський національний університет імені Івана Франка, \\ 79005 , м. Львів, вул. Драгоманова, 50 \\ Тел. (032)239-46-23, e-mail: monastyr@electronics.wups.lviv.ua
}

\section{ГАЗОАДСОРБЦЙНІ СЕНСОРНІ СТРУКТУРИ НА ОСНОВІ ПОРУВАТОГО КРЕМНІЮ}

\section{Л. С. Монастирський, І. Б. Оленич, О. І. Аксіментьєва, Б. С. Соколовський, М. Р. Павлик}

Анотація. Вивчено вплив адсорбції водню та метану на високочастотну (1 МГц) провідність і ємність сенсорних структур на основі поруватого кремнію. Зареєстровано суттєву зміну електричних параметрів в залежності від парціального тиску газів. Розраховано адсорбційну чутливість структур на основі поруватого кремнію та багатошарових структур з плівкою каталітичного матеріалу. Показано, що селективність сенсорів до водню або метану можна покращити шляхом нанесення на поверхню поруватого кремнію каталітичної плівки паладію або поліепоксіпропілкарбазолу. Виявлено помітну чутливість спектрів фотолюмінесценції поруватого кремнію до адсорбції молекул аміаку та етанолу. Отримані результати дозволяють оптимізувати процеси формування селективних сенсорів газу на основі поруватого кремнію.

Ключові слова: поруватий кремній, сенсори, адсорбція, адсорбційна чутливість, провідність, електрична ємність, фотолюмінесценція

\section{GAS ADSORPTION SENSORS ON THE BASIS OF POROUS SILICON}

\section{S. Monastyrskii, I. B. Olenych, O. I. Aksimentyeva, B. S. Sokolovskii, M. R. Pavlyk}

Abstract. The influence of hydrogen and methane adsorption on high frequency (1 MHz) conductivity and capacity of sensor structures based on porous silicon has been studied. An essential changing in electric parameters was registered as a function of partial gas pressure. It was calculated the adsorption sensitivity of porous silicon and multilayer structures with catalytic films. Sensor selectivity to hydrogen and methane may be improved by deposition on porous silicon surface the catalytic films of palladium or poly(epoxypropylcarbazole). It observed a marked sensitivity of porous silicon photoluminescence to adsorption of ammonia and ethanol. The obtained results make it possible to optimize the fabrication of selective sensors based on porous silicon.

Keywords: porous silicon, sensors, adsorption, adsorption sensitivity, conductivity, electrical capacity, photoluminescence 


\title{
ГАЗОАДСОРБЦИОННЫЕ СЕНСОРНЫЕ СТРУКТУРЫ НА ОСНОВЕ ПОРИСТОГО КРЕМНИЯ
}

\author{
Л. С. Монастырский, И. Б. Оленич, Е. И. Аксиментьева, Б. С. Соколовский, М. Р. Павлык
}

\begin{abstract}
Аннотация. Изучено влияние адсорбции водорода и метана на высокочастотную (1 МГц) проводимость и емкость сенсорных структур на основе пористого кремния. Зарегистрировано существенное изменение электрических параметров в зависимости от парциального давления газов. Рассчитана адсорбционная чувствительность структур на основе пористого кремния и многослойных структур с пленкой каталитического материала. Показано, что селективность сенсоров к водороду или метану можно улучшить путем нанесения на поверхность пористого кремния каталитической пленки палладия или полиэпоксипропилкарбазола. Выявлена заметная чувствительность спектров фотолюминесценции пористого кремния к адсорбции молекул аммиака и этанола. Полученные результаты позволяют оптимизировать процессы формирования селективных газовых сенсоров на основе пористого кремния.
\end{abstract}

Ключевые слова: пористый кремний, сенсоры, адсорбция, адсорбционная чувствительность, проводимость, электрическая емкость, фотолюминесценция

\section{Вступ}

Всебічне вивчення різноманітних властивостей поруватого кремнію (ПК) відкрило перспективу його застосування в таких галузях, як оптоелектроніка, енергетика, біомедичні технології, сенсорика. Створення напівпровідникових хімічних сенсорів $є$ важливим для контролю навколишнього середовища, атмосфери житлових і офісних приміщень, якості продуктів харчування, питної води, а також в медицині та промисловості. Використання ефекту поля у приповерхневій ділянці напівпровідника та зміна параметрів цієї ділянки під дією зовнішніх факторів, наприклад адсорбційнодесорбційних процесів у газових середовищах, лежить в основі створення сенсорних елементів «електронного носа» та «електронного язика». Матеріали з розвиненою поверхнею, такі як ПК, є надзвичайно перспективними саме в галузі сенсорної електроніки. Малі розміри кремнієвих кристалів і велика загальна площа їх поверхні зумовлює значну чутливість властивостей шарів ПК до зовнішнього середовища [1]. Зокрема, широко досліджуються адсорбційні сенсори на основі ПК, робота яких базується на зміні провідності та ємності матеріалу [2,3]. Наявність на поверхні ПК каталітичного матеріалу (наприклад, паладій або деякі провідні полімери) може сприяти підвищенню чутливості та селективності таких сенсорів [4]. 3 іншого боку, зміна молекулярного покриття поверхні ПК значним чином впливає на процеси рекомбінації носіїв заряду. Отже, варіація газового оточення повинна впливати на люмінесцентні властивості ПК, що може знайти застосування у оптоелектронних сенсорах.

\section{Експеримент}

Формування ПК відбувалось електрохімічним анодуванням кремнію р-типу провідності (КДБ-10) у водно-етанольному розчині плавикової кислоти в гальваностатичному режимі. Густина анодного струму складала $30 \mathrm{MA} / \mathrm{cm}^{2}$, а тривалість процесу анодування 20 хв. Під час електрохімічного травлення кремнію відбувається утворення вузьких пор, які напрямлені в глибину кристалу. Пори поступово розширюються, поки стінки не будуть частково розтравлені. У результаті залишаться останки стінок - так звані квантові нитки з розмірами від декількох нанометрів до десятків нанометрів в перерізі.

Для одержання каталітичної плівки паладію на поверхні ПК застосовувалось термовакуумне нанесення паладію (Pd 99,9 \%). Товщина нанесеної плівки паладію становила 100 нм. Для одержання полімерної плівки поліепоксіпропілкарбазолу (ПЕПК) застосовувалось електрохімічне осадження з розчину мономеру. В умовах електрохімічної полімеризації, коли електропровідний полімер синтезується безпосередньо на поверхні електрода, відбувалось проникнення мономеру в пори кремнію [5].

Дослідження адсорбційних процесів у структурах на основі ПК проводилось у вакуумному кріостаті, газове середовище якого 
можна було змінювати за допомогою приладу п'єзострикційного натікання газів $C H A-2$, що забезпечував контрольований напуск в діапазоні тисків $2 \cdot 10^{-8} \div 1 \cdot 10^{-1}$ атм. 3 точністю $15 \%$. Вимірювання електронних параметрів досліджуваних структур здійснювалось цифровим L, C, R вимірювачем E7-12 на частоті 1 МГц.

Люмінесцентні властивості шарів ПК досліджувались на стандартному оптичному обладнанні в спектральному діапазоні $500 \div 850$ нм. Фотолюмінесценція (ФЛ) збуджувалась імпульсним азотним лазером ЛГИ-21 з довжиною хвилі випромінювання $\lambda=337 \mathrm{Hм} \mathrm{і}$ тривалістю імпульсів 8 нс та реєструвалась через оптичний світлофільтр ЖС-17, який відсікав свічення плазми, за допомогою граткового монохроматора МДР-12 і фотоелектронного помножувача ФЕП-77. Спектри ФЛ ПК, які коректувалися 3 врахуванням спектральної чутливості установки, володіли близькою до гауссової смугою шириною $\approx 200$ нм 3 максимумом в ділянці $670 \div 680 \mathrm{нм.}$

\section{Результати та їх обговорення}

Взаємодія хімічних сполук і їх радикалів 3 поверхнею стінок між порами призводить до зміни хімічної та електронної структури поверхні нанокристалів кремнію. Як наслідок, біля поверхні формується область просторового заряду, в забороненій зоні напівпровідника утворюються локальні енергетичні рівні та відбувається вигин енергетичних рівнів на поверхні. Поверхневі стани здатні змінювати кінетику процесів, що відбуваються за участі електронів та дірок: з одного боку, вони утворюють додаткові центри рекомбінації і генерації носіїв заряду, з іншого - можуть відігравати роль проміжних рівнів енергії в процесах переносу зарядів. В результаті адсорбція газових молекул може суттєво змінювати електрофізичні параметри шарів ПК. Поряд з впливом на електронну структуру поверхні ПК, слід відзначити зміну ефективної діелектричної проникності поруватого шару внаслідок адсорбції молекул з відмінними від кремнію значеннями діелектричної проникності.

Дослідження високочастотної (1 МГц) провідності та ємності сенсорних структур на основі ПК виявили значну їх залежність від умов оточуючої атмосфери. У випадку збільшення парціального тиску метану або водню спосте- рігалося монотонне зростання електричної ємності та провідності структури ПК/Si (рис. 1a).
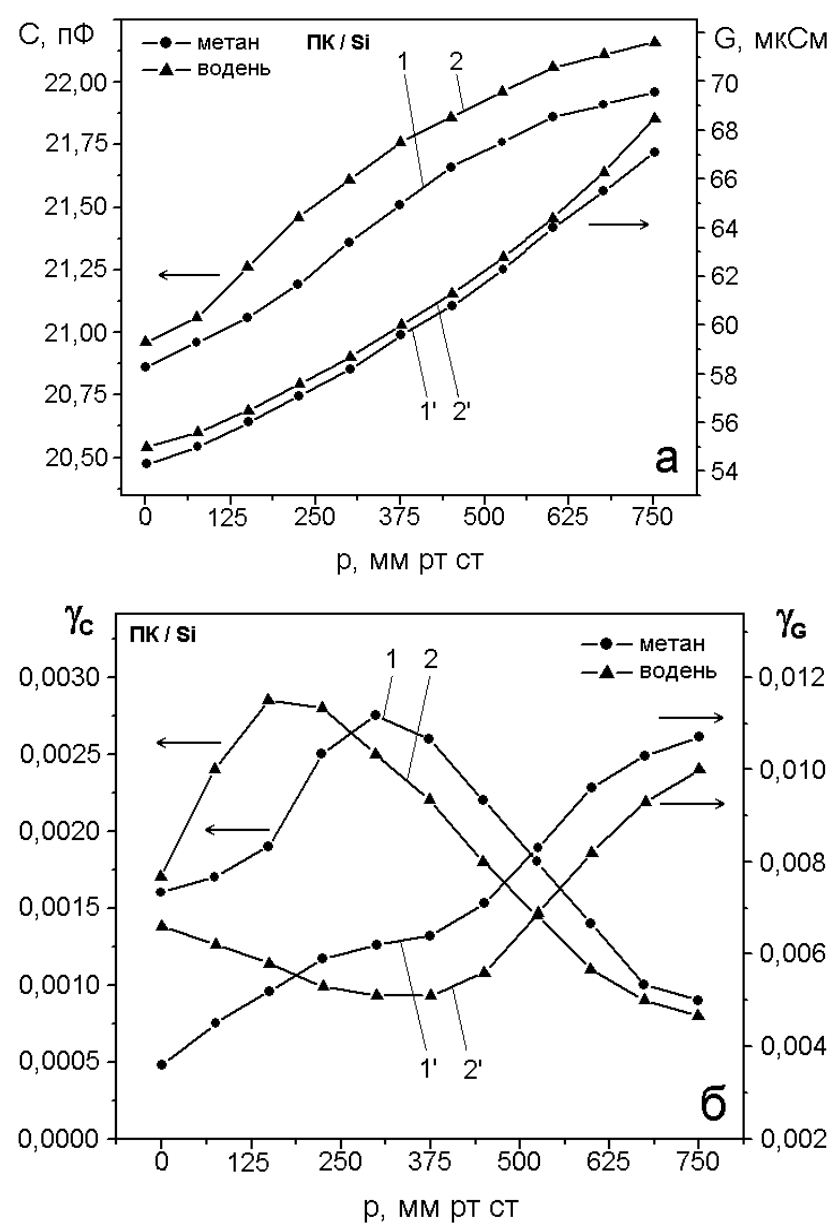

Рис. 1. Залежність ємності $(1,2)$ і провідності (1',2') (a) та адсорбційної чутливості (б) структури ПК/Si від тиску метану $\left(1,1^{\prime}\right)$ і водню $\left(2,2^{\prime}\right)$

Важливою характеристикою сенсорів у адсорбційно-десорбційних взаємодіях з газовим середовищем $€$ адсорбційна чутливість матеріалу, яка визначається за співвідношенням [6]:

$$
\gamma_{G}=\frac{1}{G} \frac{\Delta G}{\Delta p},
$$

де $\Delta G / G$ - відносна зміна провідності (для резистивних сенсорів) або ємності (у випадку ємнісних сенсорів) структури, $\Delta p-$ зміна парціального тиску газів. Експериментальні дослідження виявили, що резистивні сенсори володіють більшою на порядок адсорбційною чутливістю, ніж ємнісні (рис. 1б). Слід відзначити, що максимуми чутливості ємнісних сенсорів до водню і метану знаходяться у різних діапазонах концентрації газів.

Для структури $\mathrm{Pd} / \Pi \mathrm{K} / \mathrm{Si}$ була характерна більша зміна електричної ємності та провід- 
ності у випадку напуску в кріостат водню, ніж метану. Відповідно, адсорбційна чутливість до водню була вдвічі більшою (рис. 2). Спостерігався відгук сенсорної структури навіть на незначну концентрацію газу.
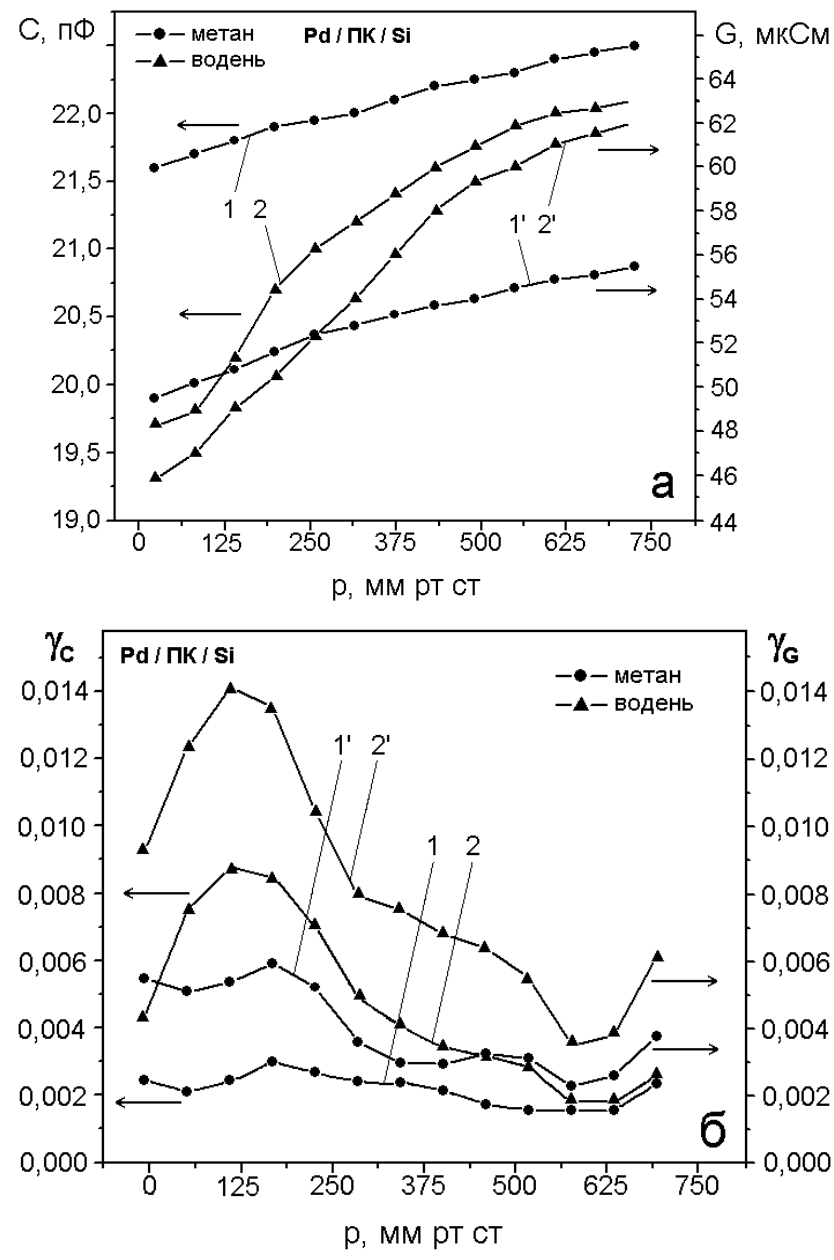

Рис. 2. Залежність ємності $(1,2)$ і провідності (1',2') (a) та адсорбційної чутливості (б) структури Pd/ПK/ Si від тиску метану $\left(1,1^{\prime}\right)$ і водню $\left(2,2^{\prime}\right)$

Характер залежностей високочастотної провідності та ємності від парціального тиску водню для структури $\mathrm{Pd} /$ ПK/Si пов'язаний 3 каталітичною дисоціацією молекул водню на мікрогранулах паладію. Утворений атомарний водень, який володіє високою проникною здатністю, проникає в глибину поруватого шару, внаслідок чого адсорбційна чутливість даної структури до водню підвищується.

Сенсорна структура ПЕПК/ПК/Si характеризувалась незначною чутливістю до молекул водню і помітним зростанням внаслідок напуску метану електричної ємності та провідності від 22,5 до 27 пФ та від 85 до 125 мкСм відповідно (рис. 3). Адсорбційна чутливість до метану також була дещо більшою ніж до водню. Спостережувана селективність структури ПЕПК/ ПК/Si може служити основою для створення твердотільного газового сенсора, який здатний виявити в оточуючому середовищі присутність метану. Такі сенсори можна було б інтегрувати в системи, сформовані на основі стандартної кремнієвої технології.
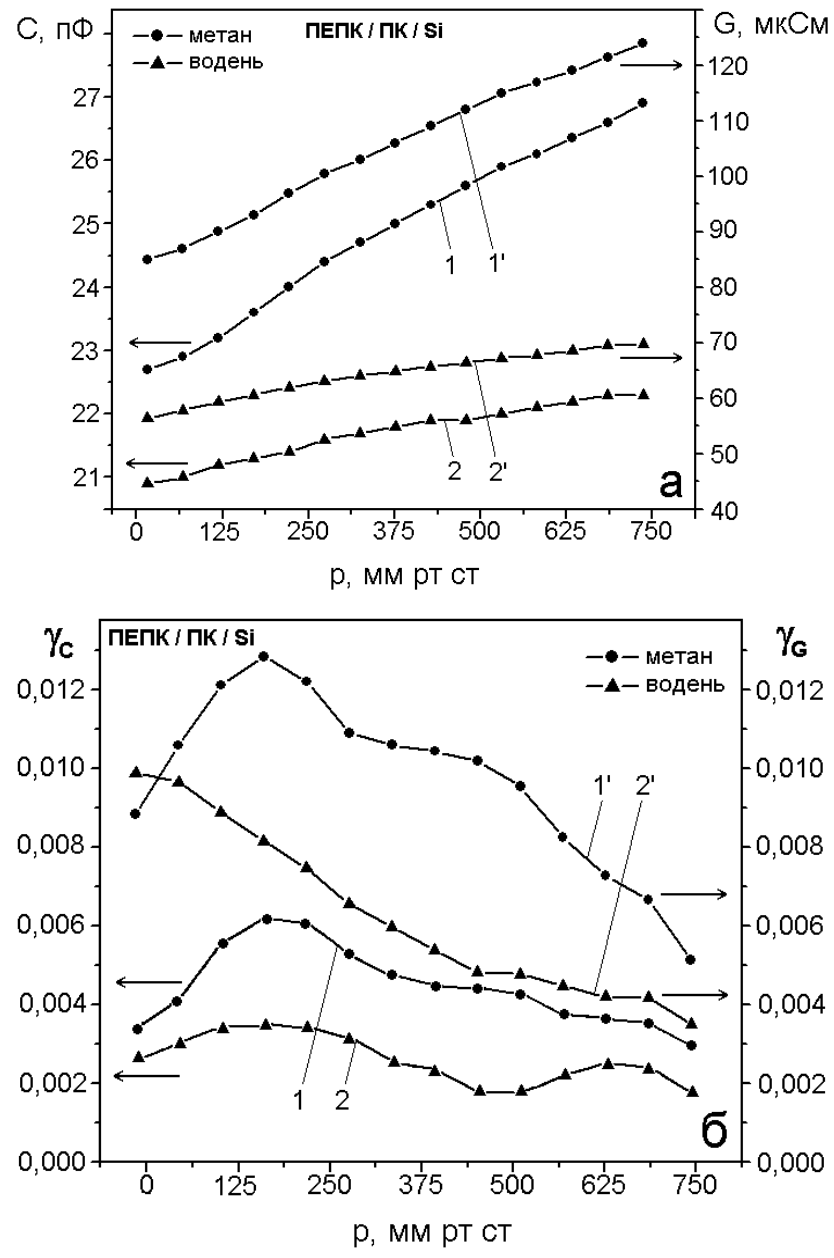

Рис. 3. Залежність ємності $(1,2)$ і провідності (1',2') (a) та адсорбційної чутливості (б) структури ПЕПК/ ПК/Si від тиску метану $\left(1,1^{\prime}\right)$ і водню $\left(2,2^{\prime}\right)$

Іншою важливою властивістю нанорозмірного ПК є здатність до ефективної фотолюмінесценції у видимому діапазоні світла [7]. Враховуючи значну питому поверхню поруватих шарів, можна очікувати, що зміна молекулярного покриття поверхні ПК буде значним чином впливати на процеси рекомбінації носіїв заряду. Дослідження виявили, що адсорбоелектричні ефекти призводять до зміни не тільки електричних, але й оптичних параметрів ПК.

Напуск у вимірювальну камеру парів етанолу та аміаку призводив до зменшення інтенсив- 
ності ФЛ поруватого кремнію у 1,25 та 2 рази відповідно (рис. 4, рис. 5). Дослідження ФЛ ПК, пори якого заповнені етанолом та $10 \%$ розчином аміаку, зареєстрували зменшення інтенсивності випромінювання в 2,5 та 8 разів відповідно у порівнянні з люмінесценцією вихідних зразків.

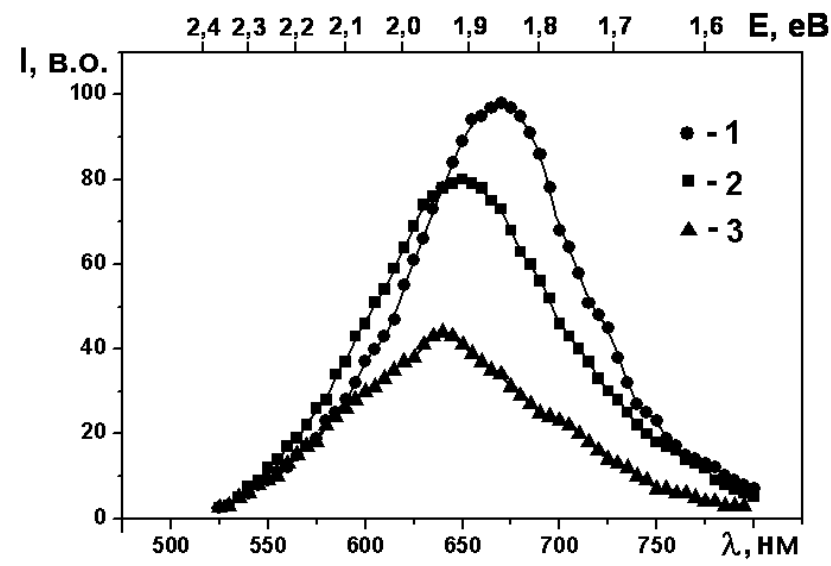

Рис. 4. Спектри фотолюмінесценції ПК: (1) - вихідний зразок, (2) - в парах етанолу, (3) - пори заповнені етанолом

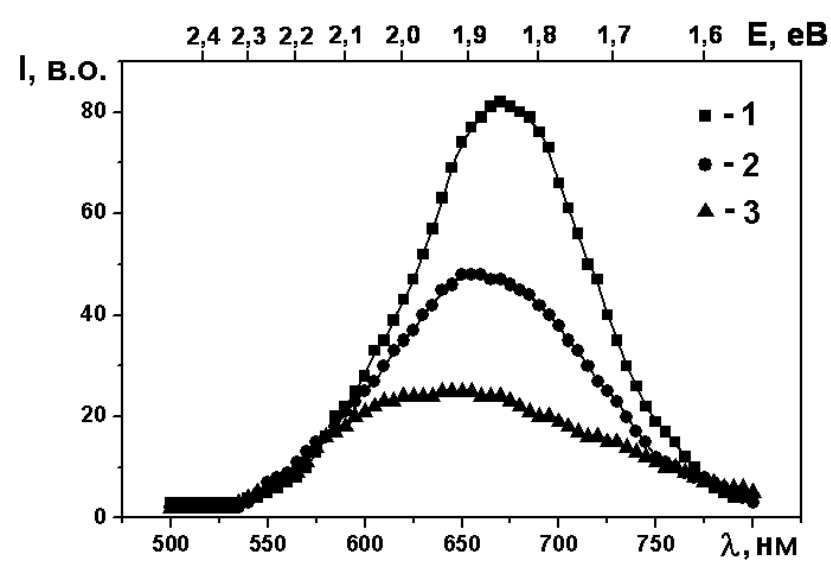

Рис. 5. Спектри фотолюмінесценції ПК: (1) - вихідний зразок, (2) - в парах аміаку, (3)×2 - пори заповнені $10 \%$ розчином аміаку

Механізм взаємодії молекул аміаку та етанолу з поверхнею кремнію пов'язаний з фізичною адсорбцією. Це підтверджує відновлення інтенсивності ФЛ після продувки та відкачування газів з кріостату. Необхідно відзначити, що хемосорбція цих газів не при кімнатній температурі не відбувається через високі значення теплоти адсорбції [8]. Фізична адсорбція молекул із значним ступенем електронегативності призводить до утворення на поверхні кремнієвих наноструктур комплексів, які змінюють величину при поверхневого заряду, а значить, і величину внутрішнього електричного поля. Отже, причиною зменшення інтенсивності люмінесценції при адсорбції молекул $\mathrm{C}_{2} \mathrm{H}_{5} \mathrm{OH}$ i $\mathrm{NH}_{3}$ може бути обмеження руху нерівноважних носіїв до центрів випромінювальної рекомбінації.

Привертає увагу той факт, що положення максимуму смуги випромінювання зміщувалося в короткохвильову область спектру на $20 \div 30$ нм для зразків з адсорбованим етанолом і на $15 \div 20$ нм для зразків з адсорбованими молекулами аміаку. У цьому випадку смуги ФЛ звужувалися за рахунок зменшення інтенсивності довгохвильової ділянки спектру. Можливою причиною спектрального зміщення максимуму люмінесценції $є$ вплив електричного поля адсорбованих полярних молекул на центри випромінювальної рекомбінації [9].

\section{Висновки}

Висока хімічна активність поверхні ПК дає можливість створити сенсори, чутливі до незначних концентрацій небезпечних для здоров'я людини речовин. Експериментальні дослідження високочастотної провідності та ємності показали, що створені структури на основі ПК володіють надзвичайно високою чутливістю до дії полярних молекул і можуть бути основою для створення датчиків газових середовищ. Підвищити селективність сенсорів на основі ПК до водню або метану можна нанесенням на робочу поверхню каталітичної плівки паладію або поліепоксіпропілкарбазолу.

Дослідження спектрів ФЛ ПК у парах етанолу та аміаку виявили чутливість смуги випромінювання як до природи адсорбованих молекул, так і до їх концентрацій, що дозволяє використати цей ефект для створення люмінесцентних сенсорів газових середовищ.

\section{Література}

1. Bisi O., Ossicini S., Pavesi L. Porous silicon: a quantum sponge structure for silicon based optoelectronics // Surface science reports. -2000 . - V. 38. P. $1-126$.

2. Rittersma Z. M. A monitoring instrument with capacitive porous silicon humidity sensors // Smart Mater. Struct. - 2000. - V.9. - P.351-356.

3. Baratto C., Faglia G., Sberveglieri G. et al. Multiparametric Porous Silicon Sensors // Sensors. 2002. - V.2. - P.121-126. 
4. Горбанюк Т. І., Євтух А. А., Литовченко В. Г. та ін. Адсорбція воднемістких молекул в багатошарових структурах з плівками пористого кремнію та паладію // Фізика іхімія твердого тіла. - 2006. T. 7, № 1. - C. 60-66.

5. Aksimentyeva O., Monastyrskyi L., Savchyn V. et al. Electronic processes in the porous silicon - conducting polymer heterostructures // Mol. Cryst. Lig. Cryst. - 2007. - V. 467. - P. 73-83.

6. Вашпанов Ю. А., Смынтына В. А. Адсорбционная чувствительность полупроводников. Одесса: Астропринт, 2005. - 216 с.
7. Canham L. T. Silicon quantum wire array fabrication by electrochemical and chemical dissolution of wafers // Appl. Phys. Lett. - 1990. - V.57. - P. 10461048.

8. Вашпанов Ю. О. Вплив адсорбції аміаку на фотолюмінесценцію неоднорідного мікропоруватого кремнію // Укр. фіз. журн. - 1999. - Т. 44, № 7. - C. 867-870.

9. Olenych I. B., Monastyrskii L. S. Influence of electric field on photoluminescence of porous silicon // Photoelectronics. - 2008. - № 17. P. $70-72$. 